\title{
SENSORY PROFILES OF CHOCOLATES PRODUCED FROM COCOA CULTIVARS RESISTANT TO Moniliophtora Perniciosa ${ }^{1}$
}

\author{
PAULA BACELAR LEITE ${ }^{2}$, ELIETE DA SILVA BISPO ${ }^{3}$, LIGIA REGINA RADOMILLE DE SANTANA ${ }^{4}$
}

\begin{abstract}
The present study evaluated the sensory quality of chocolates obtained from two cocoa cultivars (PH16 and SR162) resistant to Moniliophtora perniciosa mould comparing to a conventional cocoa that is not resistant to the disease. The acceptability of the chocolates was assessed and the promising cultivars with relevant sensory and commercial attributes could be indicated to cocoa producers and chocolate manufacturers. The descriptive terminology and the sensory profile of chocolates were developed by Quantitative Descriptive Analysis (QDA). Ten panelists, selected on the basis of their discriminatory capacity and reproducibility, defined eleven sensory descriptors, their respective reference materials and the descriptive evaluation ballot. The data were analyzed using ANOVA, Principal Component Analysis (PCA) and Tukey's test to compare the means. The results revealed significant differences among the sensory profiles of the chocolates. Chocolates from the PH16 cultivar were characterized by a darker brown color, more intense flavor and odor of chocolate, bitterness and a firmer texture, which are important sensory and commercial attributes. Chocolates from the SR162 cultivar were characterized by a greater sweetness and melting quality and chocolates from the conventional treatment presented intermediate sensory characteristics between those of the other two chocolates. All samples indicated high acceptance, but chocolates from the PH16 and conventional cultivars obtained higher purchase intention scores.
\end{abstract}

Index terms: Theobroma cacao, Witch's broom, quantitative descriptive analysis.

\section{PERFIL SENSORIAL DE CHOCOLATES PRODUZIDOS A PARTIR DE CULTIVARES DE CACAU RESISTENTES AO FUNGO Moniliophtora Perniciosa}

RESUMO - O presente estudo avaliou a qualidade sensorial de chocolates obtidos de dois cultivares de cacau (PH16 e SR162) resistentes ao fungo Moniliophtora perniciosa, comparando com uma cultivar convencional que não é resistente à doença. A aceitabilidade dos chocolates foi avaliada, as cultivares promissores com atributos sensoriais e comerciais relevantes poderão ser indicadas aos produtores de cacau e processadores de chocolates. A terminologia descritiva e o perfil sensorial dos chocolates foram desenvolvidos com base na Análise Descritiva Quantitativa (ADQ). Dez provadores, selecionados de acordo com sua capacidade de discriminação e reprodutibilidade, definiram onze descritores sensoriais, seus respectivos materiais de referência e a ficha de avaliação. Os dados foram analisados por ANOVA, Análise de Componentes Principais (ACP) e teste de Tukey, para comparação de médias. Os resultados revelaram diferenças significativas entre os perfis sensoriais dos chocolates. Os chocolates oriundos da cultivar PH16 foram caracterizados pela cor marrom mais escura, sabor e aroma de chocolate mais intenso, sabor mais amargo e textura mais firme, que são importantes atributos sensoriais e comerciais. Os chocolates oriundos da cultivar SR162 foram caracterizados pela doçura mais intensa e maior derretimento, e os chocolates provenientes da cultivar convencional apresentaram características sensoriais intermediárias entre aquelas dos outros dois chocolates. Todas as amostras apresentaram elevada aceitação, mas os chocolates das cultivares PH16 e convencional obtiveram maiores índices de intenção de compra.

Termos para indexação: Theobroma cacao, Vassoura-de-bruxa, análise descritiva quantitativa.

\footnotetext{
'(Trabalho 230-12). Recebido em: 27-08-2012. Aceito para publicação em: 09-04-2013. Parte do Projeto de Pesquisa "Caracterização e avaliação do desempenho tecnológico e sensorial de cultivares de cacau da Bahia, resistentes à vassoura-de-bruxa, para a produção de chocolates monovarietais", financiado pelo CNPq (Processo n.2010/04669-0).

${ }^{2}$ Doutoranda em Engenharia Química, Instituto de Química, UFBA, Av. Ademar de Barros s/n, 40000-000, Salvador-BA, Brasil, E-mail: bacelarleite@yahoo.com.br

${ }^{3}$ Profa. Dra. Mestrado em Ciências de Alimentos, UFBA/ Faculdade de Farmácia, Av. Ademar de Barros s/n, 40000-000, Salvador-BA, Brasil, E-mail: eliete.bispo@gmail.com

${ }^{4}$ Profa Dra. Departamento Ciências da Vida, UNEB/Faculdade de Nutrição, Av. Silveira Martins, n.2555, 41195-001, Salvador-BA, Brasil, E-mails: ligiarrs@ig.com.br, 1rsantana@uneb.br
} 


\section{INTRODUCTION}

The chocolate flavor consists of many compounds whose formation depends on the genetic profile of the cocoa, the environment where it was grown and the processing methods used. The influence of the production methods begins on the farm with post-harvest procedures, such as fermentation and drying, and continues in the chocolate processing plants. The influence of the processing on the formation of the chocolate flavor includes reactions that occur during the fermentation and drying of the cocoa beans, during the roasting of the beans, nibs or cocoa mass and in the conching of chocolate.

Chocolate is defined as the product obtained from a mixture of cocoa derivatives (Theobroma cocoa L.), cocoa mass (or paste or liquor), cocoa powder and cocoa butter, with other ingredients, containing at least $25 \%(\mathrm{~g} / 100 \mathrm{~g})$ of total solids from cocoa (BRASIL, 2005). The product may be of many forms and consistency and may be stuffed or covered. In 2010, Brazil produced 582,000 tons of chocolate, a $13 \%$ increase from 2009 , ranking third in world chocolate production, behind only the United States and Germany (ABICAB, 2012).

Currently, Theobroma cacao cultivars are recommended by the Cocoa Research Center (CEPEC/CEPLAC) to Bahia's farmers for the formation of new crops that are more productive and uniform. Creating cultivars resistant to Moniliophtora perniciosa, the fungus responsible for the cocoa disease called "Witch's broom", is a primary aim of cocoa research. Witch's broom infects the vegetative growth or reproductive parts of the cocoa tree, promoting physiological and anatomical changes in plants. Control of the Witch's broom can only be accomplished through the use of genetically resistant cultivars, which is associated with cultural handling and chemical control (REHEM, 2006).

The use of different types of cocoa can confer differences in the sensory characteristics of the chocolate. The quality and flavor of chocolate typically depend on the origin of the cocoa beans, the proportions of the ingredients used and the processing methods, which differ according to consumers' preferences and the practices of the chocolate producer (LANZA et al., 2011). Sensory analysis is a powerful scientific tool that can be used to identify differences in sensory attributes and assess product's acceptability. In research, it can be advantageous to use descriptive sensory methods. Quantitative Descriptive Analysis (QDA) is a sensory method that can be used to provide a detailed description of the sensory characteristics of a product (STONE; SIDEL, 2004). With QDA all detectable aspects of a product are described and listed by a trained panel under the guidance of a panel leader. The list is used to evaluate the product, and the panelists quantify the sensory aspects of the product using an unstructured scale (SVEINSDÓTTIR et al., 2010).

The objectives of this study were to obtain the sensory profile and the acceptability of chocolates produced from two cocoa cultivars resistant to Moniliophtora perniciosa mould, compared with a conventional cultivar that is not resistant to the disease, using a methodology based on QDA and the acceptance test.

\section{MATERIALS AND METHODS}

Three chocolate samples were evaluated (containing 67\% cocoa paste). The samples were obtained from two cultivars resistant to Moniliophtora perniciosa mould, SR162 and PH16, and from a conventional cultivar (no resistant to the mould), which was used as the control treatment. The SR162 cultivar was originated from a genetic mutation of Catongo cocoa, which is characterized by white seeds and the PH16 cultivar was obtained in a hybrid (Criollos and Forasteiros) cocoa tree population; they were recommended by the Cocoa Research Center (CEPEC/CEPLAC). The conventional cocoa sample was produced from a blend of good and sick seeds from the Pará, Parazinho and Maranhão cultivars. All of them were originated from the state of Bahia, located in the Northeast of Brazil in a tropical climate.

The chocolates were made using the following proportions: cocoa paste $(63.0 \%)$, cocoa butter $(6.6 \%)$, sugar $(30.0 \%)$ and lecithin $(0.4 \%)$. The chocolates were manufactured in a factory of the Riachuelo Farm on Ihéus-Itabuna road, state of Bahia, Brazil. The fermented and dry seeds were toasted in a circular toaster (Jaf Inox, São Paulo, Brazil) at $120^{\circ} \mathrm{C}$ for 2 hours and then triturated to remove the peel and germ, in order to obtain cocoa nibs. The nibs were ground in a knife-grinder (Jaf Inox, São Paulo, Brazil), with sugar added in this phase. The cocoa paste was then refined in a grinderroller (Jaf Inox, São Paulo, Brazil), yielding a cocoa paste with an adequate granulation $(21 \mu \mathrm{m})$ for making chocolate. The refined paste was conched, which was performed in a horizontal shell at $60{ }^{\circ} \mathrm{C}$ for 48 hours. The cocoa butter and the lecithin were added during this phase. The chocolate was conveyed to a temper machine by a shaker table and was held until it reached $42^{\circ} \mathrm{C}$, at which point the cocoa butter 
stable crystals were obtained. The chocolate was molded into $5 \mathrm{~g}$ bars using a polyethylene mold, cooled, packaged and maintained at $18{ }^{\circ} \mathrm{C}$.

QDA (STONE; SIDEL, 2004) was used to describe the differences and similarities between the chocolate samples obtained from three different cocoa cultivars. Ethical clearance approval for this study was granted by the Research Ethics Committee, Faculty of Medical Science, Federal University of Bahia-UFBA (Process ${ }^{\circ} 2011 / 1652$ ). Forty individuals participated in the recruitment (employees, researchers and students from the Pharmacy Faculty-UFBA). Fourteen candidates were prescreened on the basis of their availability, general food habits, their ability to participate in group discussions, their ability to discriminate differences between products (the Triangle Test was used) and their ability to describe their perceptions. The fourteen candidates were given four training sessions over a period of four weeks. Sensory descriptors for appearance, odor, flavor and texture were developed through brainstorming about the similarities and differences among the chocolate samples. The next step consisted in the development and definition of each descriptive term under the supervision of a leader, aiming to join similar descriptive terms and to produce reference samples using round-table consensus (Table 1). The training was finished when the fourteen individuals had no difficulty in evaluating the samples using the descriptive evaluation ballot. In a final session, each sample was evaluated in triplicate by each panelist using a complete block statistical design. Statistical evaluation was performed using an analysis of variance (ANOVA) for each descriptive term. The significance levels (p) for the $\mathrm{F}$ test (samples and replicates) were calculated for each panelist. Ten individuals were selected as panelists using the following criteria (DAMÁSIO; COSTELL, 1991): discriminatory power ( $\mathrm{p}_{\text {samples }}$ $<0.50)$ and reproducibility $\left(\mathrm{p}_{\text {replicates }} \geq 0.05\right)$.

The sensory evaluations of the samples were conducted on three series of tests. The chocolate samples $(2.5 \mathrm{~g})$ of each treatment were placed in plastic plates codified with three-digit numbers and served at room temperature $\left(22^{\circ} \mathrm{C}\right)$. The samples were presented to the panelists using a balanced complete block statistical design in order to eliminate any serving order effect. The tests were conducted in the morning, at the Laboratory of sensory analysis - UFBA, using individual booths and white light. It was recommended the use of filtered water for cleansing the palate between samples. Ten panelists rated the intensity of each sensory descriptor for each sample, in triplicate, using unstructured scales of 9 $\mathrm{cm}$, labeled on both ends with intensity terms, in the left (lower anchor) and in the right (upper anchor).

The acceptance and purchase intention tests of the three chocolate samples were conducted with sixty consumers of varied ages, who were students, professors and employees of the UFBA, using a randomized design. A nine-point structured hedonic scale ( $1=$ disliked extremely and $9=$ liked extremely) was used in the acceptance test to evaluate the appearance, odor, flavor, texture and global quality of the samples. The purchase intention was evaluated using a scale of 5 points $(1=$ certainly would not buy this product and $5=$ certainly would buy this product).

The fracture tests were conducted in chocolate samples conditioned at $25{ }^{\circ} \mathrm{C}$ using a $\mathrm{HDP} / 3 \mathrm{~PB}$ Texture Analyzer (Stable Micro Systems LTD, Surrey, England) equipped with an $8 \mathrm{~mm}$ tip diameter plunger, operating with the following conditions: 2.0 $\mathrm{mm} \mathrm{s}^{-1}$ pre-test speed, test speed and post-test speed, $10 \mathrm{~mm}$ depth and $25 \%$ strain; trigger force $0.05 \mathrm{~N}$, compression force - return to start (ASAE, 2005). The maximum force was expressed in Newtons $(\mathrm{N})$. The samples of each treatment were chocolate bars measuring $9.0 \times 2.5 \times 1.3 \mathrm{~cm}$, and the tests were conducted in triplicate.

The QDA results were evaluated by ANOVA, the sources of variance being the samples and the panelists for each sensory descriptor, using an $\mathrm{F}$ test, and Tukey's test (MSD-minimum significant difference) for multiple comparisons of means ( $\alpha$ $=0.05$ ). Principal Component Analysis (PCA) was performed on the means of the subjects in each replicate, in order to describe the main variation in the sensory data and to obtain the descriptive profiles. A correlation matrix was obtained to all quality attributes. An ANOVA for the acceptance test and the texture instrumental evaluation was performed using an $\mathrm{F}$ test, and the treatment means were compared using Tukey's multiple range test at $\alpha=0.05$. SAS statistical software (SAS, 2008) was used for all statistical analyses.

\section{RESULTS AND DISCUSSION}

According to the QDA, there were significant differences $(p<0.05)$ in the sensory quality of the chocolate samples from the cocoa cultivars studied.

Figure 1 graphically displays the sensory profile of each chocolate sample. The zero point of the descriptor scale is the center, with the intensity increasing toward the extremities of the figure. The mean value of each descriptor for each sample is marked in the corresponding axis, and the sensory profile is drawn by the connection of the points. 
The results showed that the chocolate samples differed significantly from each other (Table 2). The chocolate of PH16 cultivar was distinguished from the other samples as a result of its greater intensity in descriptors brown color, chocolate odor, chocolate flavor, bitterness and firmness and its lower intensity in sweetness and melting quality. However, the chocolate samples from SR162 demonstrated a more intense sweetness and greater melting quality. The citrus fruit flavor and the astringency presented low intensity in the three samples, and there was no significant difference $(p>0.05)$ among them (Table 2); therefore, these descriptors were considered to be not important in characterizing these products. The toasted odor and toasted flavor also presented low intensity in the three samples, but showed significant differences among them.

Figure 2 illustrates the PCA results, in which each sample is represented by a triangle. Each vertex of the triangles corresponds to the mean value attributed by the panelist group for each replicate. Samples are located near the descriptors (vectors) that characterize them. In the present study, the two principal components were used together and explained $92.6 \%$ of the total variability observed among the treatments. PCA confirmed ANOVA results. The chocolate samples from the PH16 cultivar were characterized by descriptors brown color, chocolate odor, chocolate flavor, bitterness, firmness, toasted odor and toasted flavor. The chocolate samples from the SR162 cultivar were characterized primarily by sweetness and melting quality. Chocolate samples from the conventional cultivar presented intermediate intensity for all sensory descriptors.

Thamke et al. (2009) examined the analytical skills of consumers from two different locations (Dresden, Germany and Vienna, Austria) to characterize samples of dark chocolate with cocoa contents ranging from 60 to $75 \%$. PCA was used and explained approximately $85 \%$ of the total variation between the products. The authors concluded that chocolate with the lower cocoa content was characterized by the greatest melting and creaminess while the product with the highest cocoa content was characterized as dry dough.

Lanza et al. (2011) studied the sensory characteristics of chocolate known as Sicilian Modica, using a panel of trained tasters. The panel identified a different sensory profile from other types of chocolate, due to the presence of sugar crystals and a sandy texture, resulting from its peculiar form of production. The total variability explained by the first two principal components was $75 \%$. Despite its diversity, the chocolate of Modica did not lose two sensory descriptors that are typical characteristics of chocolate: melting and cocoa flavor.

Misnawi et al. (2005) studied changes in polyphenol ability to produce astringency during roasting and fermentation of cocoa; these substances are involved in the chocolate's flavor and in the primary sensory characteristics as bitter and astringency intensity of the cocoa. The results indicated that the polyphenols were positively correlated with astringency, bitterness and green notes. The presence of different levels of polyphenols found in the products may be due to the fermentation and roasting conditions; however, polyphenols are essential for the sensory characteristics of the cocoa.

Kennedy and Heymam (2009) conducted a study of milk and dark chocolates with two panelist groups (trained and untrained), using Principal Component Analysis (PCA) and multifactor analysis to generate product maps of the descriptive analysis and projective mapping data, respectively. Visual inspection of the PCAs indicated the chocolates were primarily separated by contrasting the sweet and dairy notes with bitterness and astringency. Each panel further differentiated chocolates with terms including fruity, musty and tobacco. Panels appeared to use the descriptors fruity, caramel, dairy, astringent, cocoa and other descriptors in a similar manner, despite no effort to standardize the use of these terms across the panels. However for all panels, many of these terms were correlated with each other and grouped closely together in the PCA plots. Some of these terms may be describing related characteristics of the chocolates, especially in regard to the milk chocolates.

Luna et al. (2002) conducted a study with a sample of Ecuadorian cocoa to determine the relationship between the genotypes and the chemical constituents (polyphenols, alkaloids, organic acids and sugars) involved in the chocolate's aroma and flavor, and the primary sensory characteristics of the product (bitter, astringent intensity of the cocoa flavor, fruity acidity, floral notes and green), using a panel of trained tasters. The results indicated that the polyphenols were positively correlated with astringency, bitterness and negatively correlated with the fruity character. The presence of different levels of polyphenols found in the products may be due to either a genotypic contribution or the fermentation and roasting conditions; however, polyphenols are essential for the sensory characteristics of the cocoa.

In this study, there was high positive correlation between brown color and the descriptors chocolate odor (0.98), toasted odor (0.98), bitterness 
(0.94), toasted flavor (0.97), chocolate flavor (0.87) and firmness (0.88), as indicated in Table 3. Thus, the chocolate sample that had a more intense brown color also yielded a higher intensity in descriptors such as chocolate odor, chocolate flavor, bitterness, firmness, toasted odor and toasted flavor. Sweetness presented a high negative correlation (-0.94) with bitterness, and the same relationship was observed with toasted flavor (-0.97). The chocolate sample with a higher intensity of bitterness and toasted flavor obtained lower sweetness ratings. A high negative correlation $(-0.97)$ was also observed between the firmness and melting quality. The chocolate samples that melted quickly required less force to bite.

The results of the fracture tests showed that the chocolate samples from PH16 required greater force $(31.01 \mathrm{~N})$ to rupture while the samples from the SR162 cultivar $(23.64 \mathrm{~N})$ and conventional cultivar $(24.02 \mathrm{~N})$ required significantly $(\mathrm{p}<0.05)$ less force to rupture. According to the QDA, the chocolate samples from the PH16 cultivar were characterized by significantly $(p<0.05)$ greater firmness than the other two samples. The texture is one of principal factors used to evaluate the quality of the products by the consumers, and two other important factors are the appearance and flavor (AFOAKWA et al., 2009).

In general, the three chocolate samples showed good sensory acceptance related to all studied attributes: appearance, odor, flavor, texture and global quality. They reached score corresponding to hedonic terms "liked slightly" and "liked very much". The results of the acceptance test indicated that there were not significant differences $(p>0.05)$ in the acceptance of the three chocolate samples (Table 4). The results of the purchase intention test indicated that the attitude of the consumers was highly positive for all the chocolate samples. The purchase intention scores were $46.7 \%, 38.3 \%$ and $46.6 \%$ for the chocolate samples from the PH16, the SR162 and the conventional cultivar, respectively.

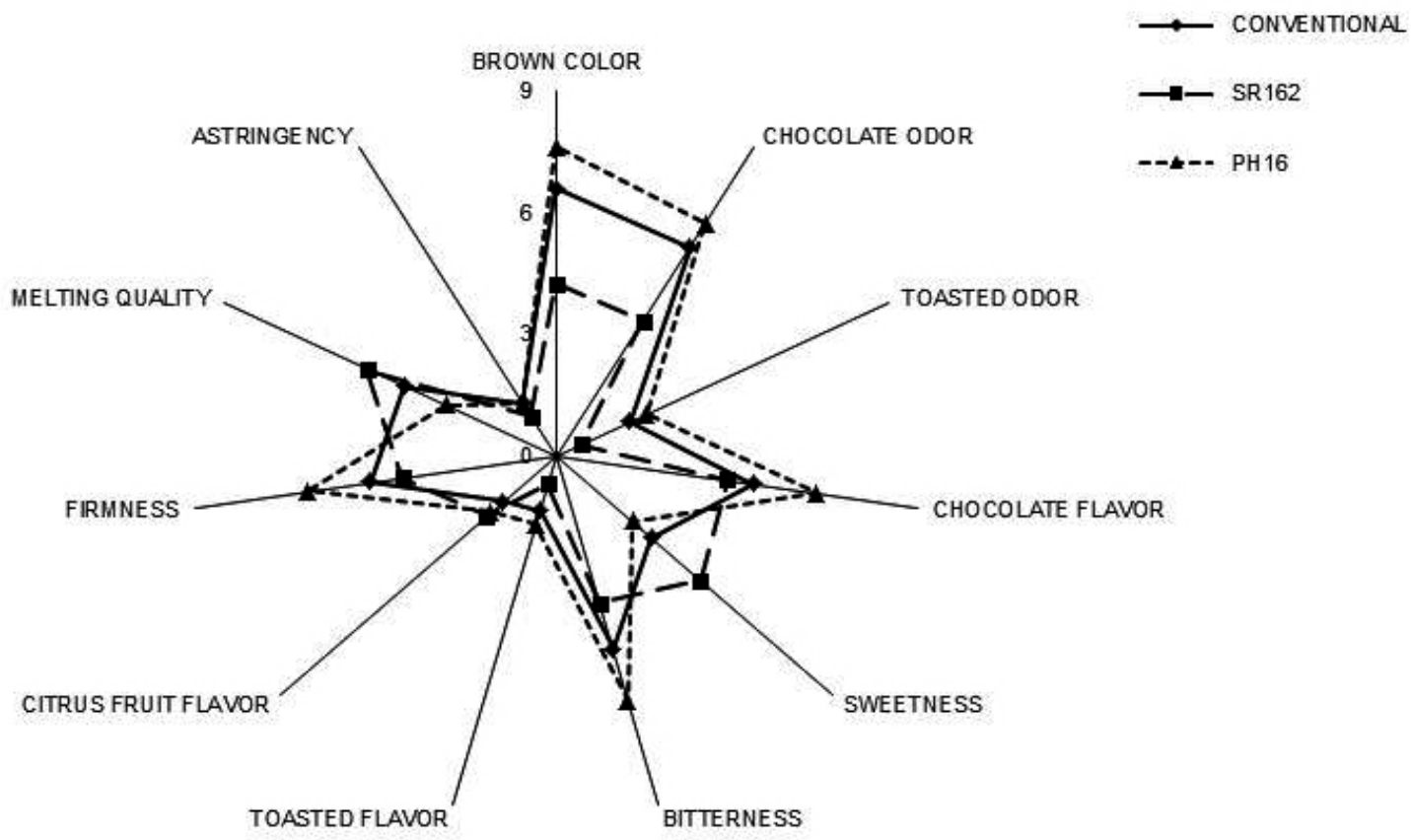

FIGURE 1 - Sensory profile of the chocolate samples produced from resistant and conventional cocoa cultivars. 
TABLE 1 - Sensory descriptors, definition and reference materials used during panel training and quantitative descriptive analysis sessions*.

\begin{tabular}{|c|c|}
\hline Sensory Descriptors & Definition and Reference Materials \\
\hline Brown Color & $\begin{array}{l}\text { Dark color between red and yellow, characteristic of chocolate. } \\
\text { Clear: alkaline cocoa powder at } 10 \% \text { added in } 100 \mathrm{~g} \text { of corn starch suspension } \\
\text { (Unilever Industrial Ltda, Pernambuco, Brazil). } \\
\text { Dark: alkaline cocoa powder at } 80 \% \text { added in } 100 \mathrm{~g} \text { of corn starch suspension } \\
\text { (Unilever Industrial Ltda, Pernambuco, Brazil). }\end{array}$ \\
\hline Chocolate Odor & $\begin{array}{l}\text { Odor related to chocolate. } \\
\text { Little: solution of chocolate powder (Nestlé Brazil Ltda, São Paulo, Brazil) } \\
\text { at } 0.25 \% \text {. } \\
\text { Much: solution of chocolate powder (Nestlé Brazil Ltda, São Paulo, Brazil) } \\
\text { at } 5.0 \% \text {. }\end{array}$ \\
\hline Toasted Odor & $\begin{array}{l}\text { Odor related to cocoa seed very toasted. } \\
\text { None: dry cocoa seed without toasting. } \\
\text { Much: cocoa seed toasted for } 3 \text { hours. }\end{array}$ \\
\hline Chocolate Flavor & $\begin{array}{l}\text { Residual flavor of dark chocolate. } \\
\text { Little: milk chocolate (Nestlé Brazil Ltda, São Paulo, Brazil). } \\
\text { Much: dark chocolate } 70 \% \text { cacao (Nestlé Brazil Ltda, São Paulo, Brazil). }\end{array}$ \\
\hline Sweetness & $\begin{array}{l}\text { Sweet taste obtained from table sugar. } \\
\text { Little: solution of table sugar (União Ltda, São Paulo, Brazil) at 1.0\%. } \\
\text { Much: solution of table sugar (União Ltda, São Paulo, Brazil) at 10.0\%. }\end{array}$ \\
\hline Bitterness & $\begin{array}{l}\text { The unpleasant taste of caffeine. } \\
\text { None: pure water. } \\
\text { Much: solution of caffeine (Food Degree, São Paulo, Brazil) at } 0.1 \% \text {. }\end{array}$ \\
\hline Toasted Flavor & $\begin{array}{l}\text { Flavor related to cocoa very toasted. } \\
\text { None: dry cocoa seed without toasting. } \\
\text { Much: cocoa seed toasted for } 3 \text { hours. }\end{array}$ \\
\hline Citrus Fruit Flavor & $\begin{array}{l}\text { Flavor related to tangerine fruit. } \\
\text { None: pure water. } \\
\text { Much: solution of essential oil of tangerine. }\end{array}$ \\
\hline Firmness & $\begin{array}{l}\text { Force needed to bite through the chocolate sample. } \\
\text { Little firm: milk chocolate (Nestlé Brazil Ltda, São Paulo, Brazil) } \\
\text { Much firm: dark chocolate } 70 \% \text { cacao (Nestlé Brazil Ltda, São Paulo, Brazil). }\end{array}$ \\
\hline Melting Quality & $\begin{array}{l}\text { Length of time for chocolate to melt in the mouth. } \\
\text { Little: dark chocolate } 70 \% \text { cacao (Nestlé Brazil Ltda, São Paulo, Brazil) } \\
\text { warmed in a microwave oven for } 20 \text { seconds. } \\
\text { Much: dark chocolate } 70 \% \text { cacao (Nestlé Brazil Ltda, São Paulo, Brazil) } \\
\text { warmed in a microwave oven for } 40 \text { seconds. }\end{array}$ \\
\hline Astringency & $\begin{array}{l}\text { Drying sensation from tasting cocoa powder or green fruit. Contraction of } \\
\text { mouth mucus. } \\
\text { None: milk chocolate (Nestlé Brazil Ltda, São Paulo, Brazil). } \\
\text { Much: dark chocolate } 70 \% \text { cacao (Nestlé Brazil Ltda, São Paulo, Brazil). }\end{array}$ \\
\hline
\end{tabular}

*Results expressed on unstructured scales of $9 \mathrm{~cm}$ labeled on both ends, with intensity terms in the left (lower anchor) and in the right (upper anchor). 


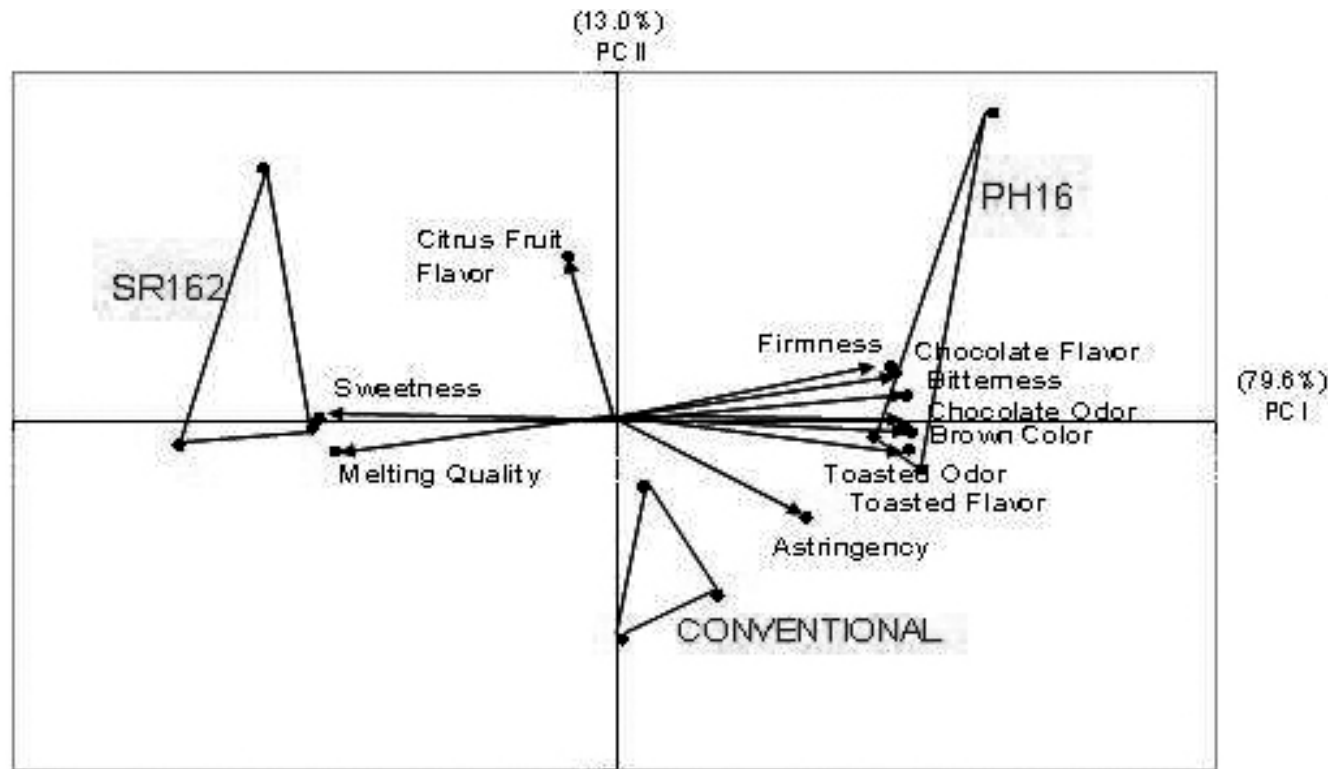

FIGURE 2 - Principal Component Analysis (PCA) of sensory data of chocolate samples produced from resistant and conventional cocoa cultivars. PCA loadings and scores for principal component 1 and 2 , including all evaluated sensory descriptors.

TABLE 2 - Means of sensory descriptors that characterized the chocolate samples produced from resistant and conventional cocoa cultivars.

\begin{tabular}{ccccc}
\hline Descriptor & PH16 & SR162 & Conventional & SMD \\
\hline Brown Color & $7.60^{\mathrm{a}}$ & $4.22^{\mathrm{c}}$ & $6.58^{\mathrm{b}}$ & 0.41 \\
Chocolate Odor & $6.78^{\mathrm{a}}$ & $3.95^{\mathrm{c}}$ & $6.09^{\mathrm{b}}$ & 0.55 \\
Toasted Odor & $2.50^{\mathrm{a}}$ & $0.72^{\mathrm{c}}$ & $2.05^{\mathrm{b}}$ & 0.32 \\
Chocolate Flavor & $6.49^{\mathrm{a}}$ & $4.26^{\mathrm{b}}$ & $4.90^{\mathrm{b}}$ & 0.72 \\
Sweetness & $2.49^{\mathrm{c}}$ & $4.69^{\mathrm{a}}$ & $3.11^{\mathrm{b}}$ & 0.58 \\
Bitterness & $6.29^{\mathrm{a}}$ & $3.80^{\mathrm{c}}$ & $4.96^{\mathrm{b}}$ & 0.76 \\
Toasted Flavor & $1.83^{\mathrm{a}}$ & $0.79^{\mathrm{b}}$ & $1.47^{\mathrm{a}}$ & 0.48 \\
Citrus Fruit Flavor & $2.15^{\mathrm{a}}$ & $2.30^{\mathrm{a}}$ & $1.76^{\mathrm{a}}$ & 0.69 \\
Firmness & $6.16^{\mathrm{a}}$ & $3.83^{\mathrm{b}}$ & $4.64^{\mathrm{b}}$ & 0.85 \\
Melting Quality & $2.98^{\mathrm{c}}$ & $5.10^{\mathrm{a}}$ & $4.10^{\mathrm{b}}$ & 0.95 \\
Astringency & $1.53^{\mathrm{a}}$ & $1.14^{\mathrm{a}}$ & $1.53^{\mathrm{a}}$ & 0.49 \\
\hline
\end{tabular}

For each attribute, means $(\mathrm{n}=3)$ in the same line accompanied by the same letter no differ significantly, according to Tukey test $(\mathrm{p} \leq 0.05)$. SMD = significative minimum difference (Tukey's test).

PH16 and SR162= cultivars resistant to Moniliophtora pernicios ; Conventional= no resistant.

TABLE 3 - Correlation coefficients between the sensory descriptors obtained from principal component analysis of chocolate samples produced from resistant and conventional cocoa cultivars.

\begin{tabular}{|c|c|c|c|c|c|c|c|c|c|c|}
\hline & \multirow{2}{*}{\multicolumn{10}{|c|}{ BROC CHOO TOAO CHOF SWET BITT TOAF CIFF FIRM MELT ASTR }} \\
\hline BROC & 1.00 & & & & & & & & & \\
\hline CHOO & 0.98 & 1.00 & & & & & & & & \\
\hline TOAO & 0.98 & 0.97 & 1.00 & & & & & & & \\
\hline CHOF & 0.87 & 0.84 & 0.86 & 1.00 & & & & & & \\
\hline SWET & -0.98 & -0.97 & -0.99 & -0.88 & 1.00 & & & & & \\
\hline BITT & 0.94 & 0.92 & 0.92 & 0.96 & -0.94 & 1.00 & & & & \\
\hline TOAF & 0.97 & 0.96 & 0.98 & 0.88 & -0.97 & 0.92 & 1.00 & & & \\
\hline CIFF & -0.23 & -0.32 & -0.20 & 0.11 & 0.16 & -0.02 & -0.16 & 1.00 & & \\
\hline FIRM & 0.88 & 0.86 & 0.84 & 0.95 & -0.87 & 0.96 & 0.85 & 0.08 & 1.00 & \\
\hline MELT & -0.88 & -0.88 & -0.84 & -0.89 & 0.88 & -0.93 & -0.84 & 0.02 & -0.97 & 1.00 \\
\hline ASTR & 0.64 & 0.68 & 0.59 & 0.42 & -0.58 & 0.58 & 0.62 & -0.47 & 0.48 & -0.48 \\
\hline
\end{tabular}

BROC: Brown color; CHOO: chocolate odor; TOAO: toasted odor; CHOF: chocolate flavor; SWET: sweetness; BITT: bitterness; TOAF: toasted flavor; CIFF: citrus fruit flavor; FIRM: firmness; MELT: melting quality; ASTR: astringency. 
TABLE 4 - Sensory acceptance means of the chocolate samples produced from resistant and conventional cocoa cultivars.

\begin{tabular}{ccccc}
\hline Attributes & PH16 & SR162 & Conventional & SMD \\
\hline Appearance & $7.51 \mathrm{a}$ & $7.78 \mathrm{a}$ & $7.56 \mathrm{a}$ & 0.49 \\
Odor & $6.61 \mathrm{a}$ & $6.90 \mathrm{a}$ & $6.98 \mathrm{a}$ & 0.85 \\
Flavor & $6.10 \mathrm{a}$ & $5.60 \mathrm{a}$ & $6.05 \mathrm{a}$ & 0.63 \\
Texture & $7.05 \mathrm{a}$ & $7.15 \mathrm{a}$ & $7.05 \mathrm{a}$ & 0.53 \\
Global Quality & $6.43 \mathrm{a}$ & $6.30 \mathrm{a}$ & $6.50 \mathrm{a}$ & 0.79 \\
\hline
\end{tabular}

For each attribute, means $(n=60)$ in the same line accompanied by the same letter no differ significantly, according to Tukey test ( $\mathrm{p} \leq 0.05)$. SMD $=$ significative minimum difference (Tukey's test).

PH16 and SR162 $=$ cultivars resistant to Moniliophtora pernicios $a$; Conventional $=$ no resistant.

\section{CONCLUSIONS}

1-There was significant difference among the chocolate samples according to Quantitative Descriptive Analysis and the Principal Component Analysis explained $96.6 \%$ of total variability. The chocolate samples from the PH16 cultivar were characterized by a higher intensity of brown color, chocolate odor, chocolate flavor, bitterness and firmness. The chocolate samples from the SR162 cultivar were characterized primarily by sweetness and melting quality. The chocolate samples from the conventional cultivar presented an intermediate intensity for all sensory descriptors studied. The three chocolate samples showed good sensory acceptance related to all studied attributes (appearance, odor, flavor, texture and global quality), without significant differences among them.

2-High correlations were found among sensory characteristics, as positive correlation of chocolate odor, chocolate flavor, bitterness, toasted odor and toasted flavor with brown color, and negative correlation of bitterness and toasted flavor with sweetness, firmness and melting quality.

\section{REFERENCES}

ABICAB - Associação Brasileira da Industria de Chocolates, Cacau, Amendoim, Balas e Derivados.. Exportação. Disponível em: $<$ http://www.abicab. org.br>. Acesso em: 12 abr. 2012.

AFOAKWA, E.O.; PATERSON, A.; FOWLER, M.; VIEIRA, J. Microstructure and mechanical properties related to particle size distribution and composition in dark chocolate. International Journal of Food Science and Technology, Oxford, v. 44, p.111-119, 2009.
ASAE - American Society of Agricultural Engineers. Agricultural engineers yearbook of standards. $16^{\text {th }}$ ed. St. Joseph, 2005.

BRASIL. Ministério da Saúde. Agência Nacional de Vigilância Sanitária. Legislação. VisaLegis. Resolução RDC No 264, de 22 de setembro de 2005. Regulamento técnico para chocolate e produtos de cacau. Disponível em: $<\underline{\text { http://e-legis.bvs.br/leisref/ }}$ public/showAct.php>. Acesso em: 06 mar. 2012.

DAMASIO, M.H.; COSTELL, E. Análisis sensorial descriptivo: generación de descriptores y seleción de catadores. Revista Agroquímica de Technología de Alimentos, San Jose, v. 31, n. 2, p. 165-178, 1999.

KENNEDY, J.; HEYMANN, H. Projective Mapping and descriptive analysis of milk and dark chocolates. Journal of Sensory Studies, Washington, v. 24, n.1, p.220-233, 2009.

LANZA, C.M.; MAZZAGLIA, A.; PAGLIARINI, E. Sensory profile of a specialty sicilian chocolate. International Journal of Food Science, Oxford, v. 23, p.36-44, 2011.

LUNA, F.; CROUZILlAT, D.; CIROU, L.; BUCHELI, P. Chemical composition and flavor of Ecuadorian cocoa liquor. Journal of Agricultural Food Chemistry, Washington, v. 50, n.12, p.35273532, 2002.

MISNAWI, J.S.; JINAP, S.; JAMILAH, B.; NAZAMID, S. Achanges in polyphenol ability to produce astringency during roasting of cocoa liquor. Journal of the Science of Food and Agriculture, London, v. 85, n. 6, p. 917-924, 2005.

REHEM, B.C. Respostas fisiológicas de clones de Theobroma cacao L. ao alagamento do substrato. 2006. 72 f. Dissertaçãp (Mestrado) - Universidade de Santa Cruz, Ilhéus, 2006. 
SAS - Statistical Analysis System for windows. User's procedures guide. Version 6. Cary, 2008. 2v.

STONE, H.; SIDEL, J.L. Sensory evaluation pratices. 3.ed. London: Elsevier Academic Press, 2004. 377 p. (Food Science and Technology. International Series).
SVEINSDÓTTIR, K.; MARTINSDÓTTIR, E.; HYLDIG, G.; SIGURGÍSLADÓTTIR, S. Sensory Characteristics of Different Cod Products. Journal of Sensory Studies, Chicago, v. 25, p.294-314, 2010.

THAMKE, I.; DURRSCHMID, K.; ROHMA, H. Sensory description of dark chocolates by consumers. Food Science Technology, Chicago, v. 42, p.534539, 2009. 1 